\title{
Efficiency of photo identification of inguinal color patterns of Pithecopus gonzagai (Anura: Phyllomedusidae) from northeastern Brazil
}

\author{
Frede Lima-Araujo, ${ }^{1}$ Ana Carolina Brasileiro, ${ }^{1}$ Elvis Franklin Fernandes Carvalho, ${ }^{1}$ and Daniel \\ Cunha Passos ${ }^{2}$ \\ ${ }^{1}$ Universidade Federal do Ceará - UFC, Programa de Pós-Graduação em Ecologia e Recursos Naturais - PPGERN, \\ Departamento de Biologia. Campus Pici, 60440-900, Fortaleza, CE, Brazil. E-mail: fred.bio.ma@gmail.com. \\ ${ }^{2}$ Universidade Federal Rural do Semiárido - UFERSA, Programa de Pós-Graduação em Ecologia e Conservação - PPGEC, \\ Laboratório de Ecologia e Comportamento Animal - LECA. 59625-900, Mossoró, Rio Grande do Norte, RN, Brazil. \\ E-mail: daniel.passos@ufersa.edu.br.
}

\begin{abstract}
Efficiency of photo identification of inguinal color patterns of Pithecopus gonzagai (Anura: Phyllomedusidae) from northeastern Brazil. Animal monitoring research involving mark-recapture techniques increasingly requires non-invasive methods of individual identification. The photographic identification method (PIM) is an excellent tool for this purpose and has been applied successfully to many taxa. However, the utility of PIM is a function of species-specific features that are judged suitable for a given targetspecies. Herein, the suitability of inguinal color patterns for photo identification of individuals of Pithecopus gonzagai are evaluated by comparing two widely used computerassisted photographic matching programs (I3 3 and Wild.ID). Both programs accurately identified more than $70 \%$ of individuals in the top 20 potential matching photographs. Wild.ID was slightly better than ${ }^{3} S$ in matching efficiency and has a faster processing time. Thus, PIM is useful to identify individual P. gonzagai; however, before implementing the technique in animal-monitoring studies of other taxa, one must evaluate the suitability PIM for the target species and calibrate the relative efficiency of the software programs in identifying individuals.
\end{abstract}

Keywords: Anurans, individual identification, mark-recapture method, $\mathrm{I}^{3} \mathrm{~S}$, Wild.ID.

\section{Resumo}

Eficiência da fotoidentificação dos padrões de cores inguinais de Pithecopus gonzagai (Anura: Phyllomedusidae) do nordeste do Brasil. A pesquisa de monitoramento de animais envolvendo técnicas de marcação-recaptura requer cada vez mais métodos não invasivos de identificação individual. O método de identificação fotográfica (PIM) é uma excelente ferramenta para esse propósito e tem sido aplicado com sucesso a diversos táxons. No entanto, a utilidade do

Received 05 February 2020

Accepted 05 May 2021

Distributed June 2021 


\begin{abstract}
PIM é em função de características específicas da espécie que são julgadas adequadas para uma determinada espécie-alvo. Aqui, a adequação dos padrões de cores inguinais para identificações fotográficas de indivíduos de Pithecopus gonzagai é avaliada comparando dois programas amplamente usados de correspondência fotográfica assistida por computador (I3S e Wild.ID). Ambos os programas identificaram com precisão mais de 70\% dos indivíduos nas 20 melhores fotografias possíveis. Wild. ID foi ligeiramente melhor do que $\mathrm{I}^{3} \mathrm{~S}$ em eficiência de correspondência e tem um tempo de processamento mais rápido. Assim, PIM é útil para identificação individual de $P$. gonzagai; entretanto, antes de implementar a técnica em estudos de monitoramento animal em outros táxons, deve-se avaliar a adequação do PIM para as espécies-alvo e calibrar a eficiência relativa dos programas de software na identificação de indivíduos.
\end{abstract}

Palavras-chave: anuros, identificação individual, método de recaptura de marca, I3S, Wild.ID.

\section{Introduction}

Individual recognition is essential to several kinds of biological studies, such as faunal monitoring, population demography, and behavioral ecology. However, to select the most appropriate way to identify individuals of a target species, one must carefully evaluate the benefits and disadvantages of various techniques for the specific system; biological constraints, financial costs, and any inherent ethical issues associated with a given taxon should be considered (Langkilde and Shine 2006, Caorsi et al. 2012). For example, despite the widespread usage of toe clipping and subcutaneous implants (elastomer or tags) in anurans (Brow 1997), these methods are invasive and controversial because their use may be harm the frog, especially in arboreal species in which adhesive discs are essential to perch (e.g., Clarke 1972, May 2004, Funk et al. 2005).

The Photographic Identification Method (PIM) is a useful, non-invasive marking alternative that can be used to distinguish individuals of species that possess characteristic features or natural markings (Würsig and Würsig 1977, Long and Azmi 2017). Many computerassisted systems (pattern recognition or photographic matching software) have been developed that enable researchers to process large numbers of photographic images in relatively short timeframes. Thus, due to its biological, logistic, financial and ethical advantages, PIM has been increasingly used in research studies of an array of taxa, such as insects and sea stars (Chim and Tan 2012, Caci et al. 2013), sharks and rays (Tienhoven et al. 2007, Marshall and Pierce 2012), marine and freshwater teleost fishes (Correia et al. 2014, Dala-Corte et al. 2016), aquatic and terrestrial mammals (Kniest et al. 2010, Bolger et al. 2012), and turtles and lizards (Knox et al. 2013, Long and Azmi 2017), as well as toads and salamanders (Gamble et al. 2008, Caorsi et al. 2012).

Among anurans, hylid treefrogs comprise one of the largest families, with more than 750 described species (Frost 2018). Hylidae, Pelodryadidae (ca. 210 sp.), and Phyllomedusidae (ca. 70 sp.) compose the Arboranae lineage, which includes primarily arboreal species (Duellman et al. 2016). Many arboranan species have distinctive color patterns on the flanks, groins, or legs; these patterns do not change and thus, are suitable to track individuals in markrecapture studies (e.g., Kenyon et al. 2009, Del Lama et al. 2011, Kim et al. 2017). We choose the arboreal phyllomedusid Pithecopus gonzagai Andrade, Haga, Ferreira, Recco-Pimentel, Toledo, and Bruschi, 2020 [previously included with $P$. nordestinus (Caramaschi, 2006) (Caramaschi 2006, Vilaça et al. 2011, Andrade et al. 2020)] as a target species because its morphological, ecological, and ethological 
features make it an excellent model for behavioral studies (Brasileiro et al. 2020, 2021). First, like most phyllomedusids, $P$. gonzagai has contrasting and colorful inguinal patterns (Figure 1) which make it highly suitable for individual identification (Oliveira et al. 2012). Second, individual frogs are easily habituated to humans, allowing for detailed recording of several stereotyped behaviors (e.g., fighting, Brasileiro et al. 2020). To validate the suitability and efficiency of PIM in P. gonzagai, we (1) assessed the use of inguinal color patterns in this species as a natural mark for individual identification and (2) evaluated the relative efficiency of two popular photographic image-matching programs for recognition of individual frogs.

\section{Materials and Methods}

Fieldwork was carried out in a temporary pond (0352'4.02" S, 40²2'12.06" W; WGS84; $110 \mathrm{~m}$ a.s.1.; $1.058 \mathrm{~m}^{2}$ of perimeter) belonging to the Rio Acaraú Basin, in the municipality of Groaíras, state of Ceará, northeastern Brazil. The study site is dominated by herbaceous vegetation (Figure 2) but is surrounded by open phytophysiognomies typical of the Caatinga Domain, including thorny and deciduous shrublands, as well as Carnaúba [Copernicia prunifera (Mill.) H.E.Moore] forest (Moro et al. 2015). Data were collected from February-June 2017. We captured individual Pithecopus gonzagai by active visual and acoustic searches around the margins of ponds where the tree frogs vocalized and spawned from 18:00-00:00 h, for a total of $37 \mathrm{~h}$ of sampling effort. The specimens were captured at random throughout the sampling period. For each frog captured/recaptured, one of us (FLA) took standardized photographs of the flanks with the inguinal color-pattern exposed (Figure 1). We released the individuals at their site of capture. Photographs were taken with a Sony DSC HX200V digital camera (f/4.5, $1 / 160$ s, ISO-400). All the sampling procedures were performed under authorization of Brazilian environmental agencies (ICMBio license $\mathrm{n}^{\circ}$ 13587).

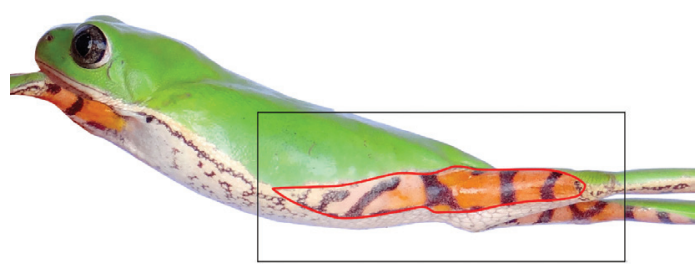

Figure 1. Inguinal color pattern of Pithecopus gonzagai composed of black stripes on an orange background. The region used for individual identification is delimited with a rectangle.

We selected the best photograph of each frog based on the focal quality and light exposure (but including slightly different angles) and cropped the images to encompass only the left inguinal region (Figure 1). The images were then compiled in a catalog to be submitted to matching process as follows. First, we performed a visual identification method (VIM) in which three researchers did a pairwise comparison of each photograph with the entire catalogue without any computer assistance. Second, we performed computer-assisted PIM, submitting the catalogue to two independent photographic imagematching programs, $\mathrm{I}^{3} \mathrm{~S}$ (Tienhoven et al. 2007) and Wild.ID (Bolger et al. 2012).

The ${ }^{3} \mathrm{~S}$ software-Interactive Individual Identification System (available at http://www. reijns.com/i3s/)-delimits key-points of matching in each image, and presents a list of potential matching photographs, from which the user can identify the exact matching; see application in Town et al. (2013). The Wild.ID software (available at http://wildid.teamnetwork. org/index.jsp) automatically performs pattern recognition and matching, and also presents a rank of 20 most similar photographs classified according similarity; see application in DalaCorte et al. (2016). The subset of the 20 most likely matches generated by each program was followed by inspection by human observers to evaluate a possible correct match in the lists.

For analytical purposes, we assumed that VIM precisely recovered all the recaptures of 


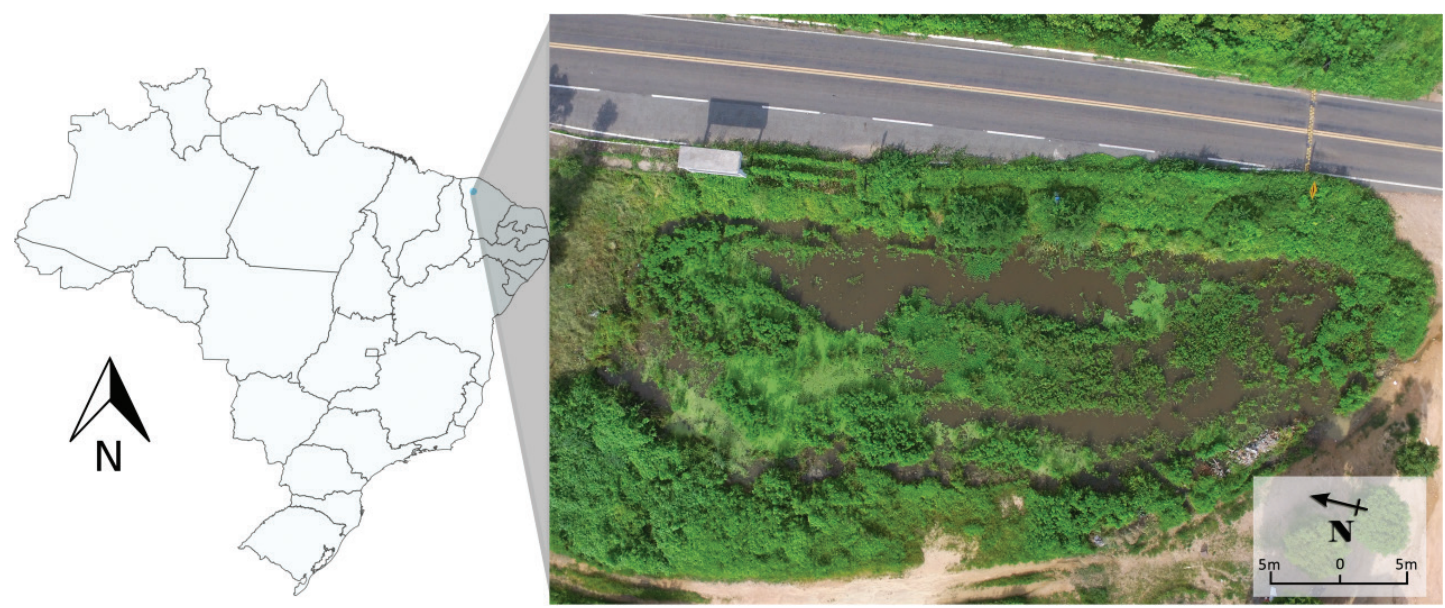

Figure 2. Location of the study site, a temporary pond at the municipality of Groaíras, state of Ceará in northeastern Brazil.

our dataset. To evaluate the efficiency of software tested in the PIM of Pithecopus gonzagai, we compared the performance of each program with respect to two criteria: (1) the rate of correct matching (number of correct identification/total number of recaptures by VIM); and (2) how long the image processing took (the average time in seconds to import the photographs from the catalog and to select the area of interest-i.e., the inguinal region). The rate of correct identification was calculated based in the entire catalogue (123 photographs), checking if each target photograph was included among the 20 first potential matching photographs provided by both programs. The duration of image processing was calculated for each program based in average time spent to import and select the inguinal region of 60 images.

\section{Results}

We recorded 26 recaptures by VIM; therefor, this total was used as the reference to compare the efficiency of the photographic imagematching programs. The rates of correct matching were quite similar. The Wild.ID
(Figure 3) calculated $76.9 \%(N=20$ recaptures) correctly, and the $\mathrm{I}^{3} \mathrm{~S}$ (Figure 4 ) calculated $73.1 \%$ $(N=19$ recaptures) correctly.

Image processing in Wild.ID was much faster than in $\mathrm{I}^{3} \mathrm{~S}$. The Wild.ID took 105 seconds to import the 60 photographs (average of 1.75 seconds per image), whereas $\mathrm{I}^{3} \mathrm{~S}$ required more than 100 minutes (average of 100.72 seconds per image).

\section{Discussion}

Inguinal color patterns of Pithecopus gonzagai can be used to identify individual frogs, thereby allowing the implementation of photographic identification methods. Visual identification without computer assistance may be more accurate than some computer-assisted programs (Kim et al. 2017); however this technique requires so much time to analyze a large database, that it is practically unfeasible (Markowitz et al. 2003, Carter et al. 2014). Thus, many authors recommend its use as a supplement to computerassisted systems of pattern recognition (Gamble et al. 2008, Del Lama et al. 2011). 

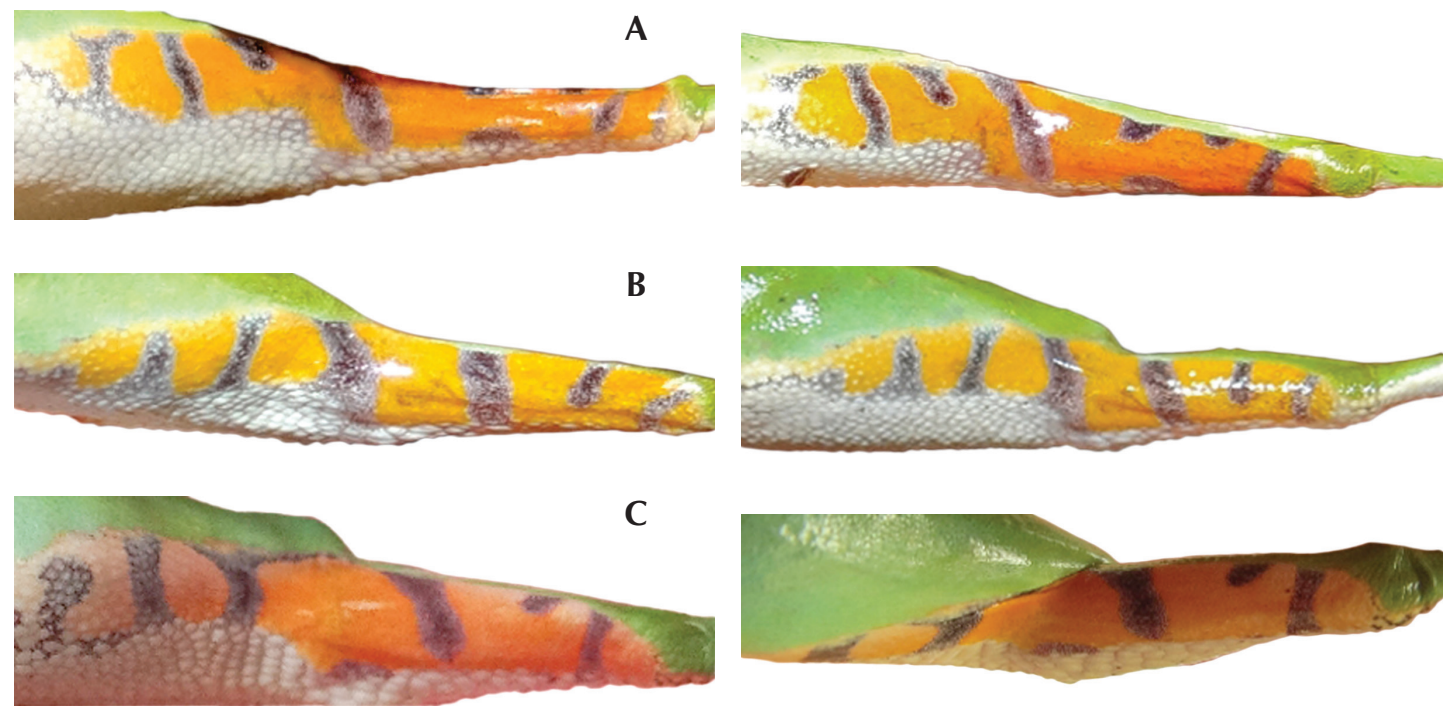

Figure 3. Results of three recapture matches with Wild.ID. Images in the left column correspond to focal images, and those in the right column correspond to the images with a high level of correspondence. Images (A) and (B) have the best level of correspondence (level 01 of 20), whereas image (C) has a relatively low level of correspondence (level 18 of 20), probably a result of the angle of the photograph.
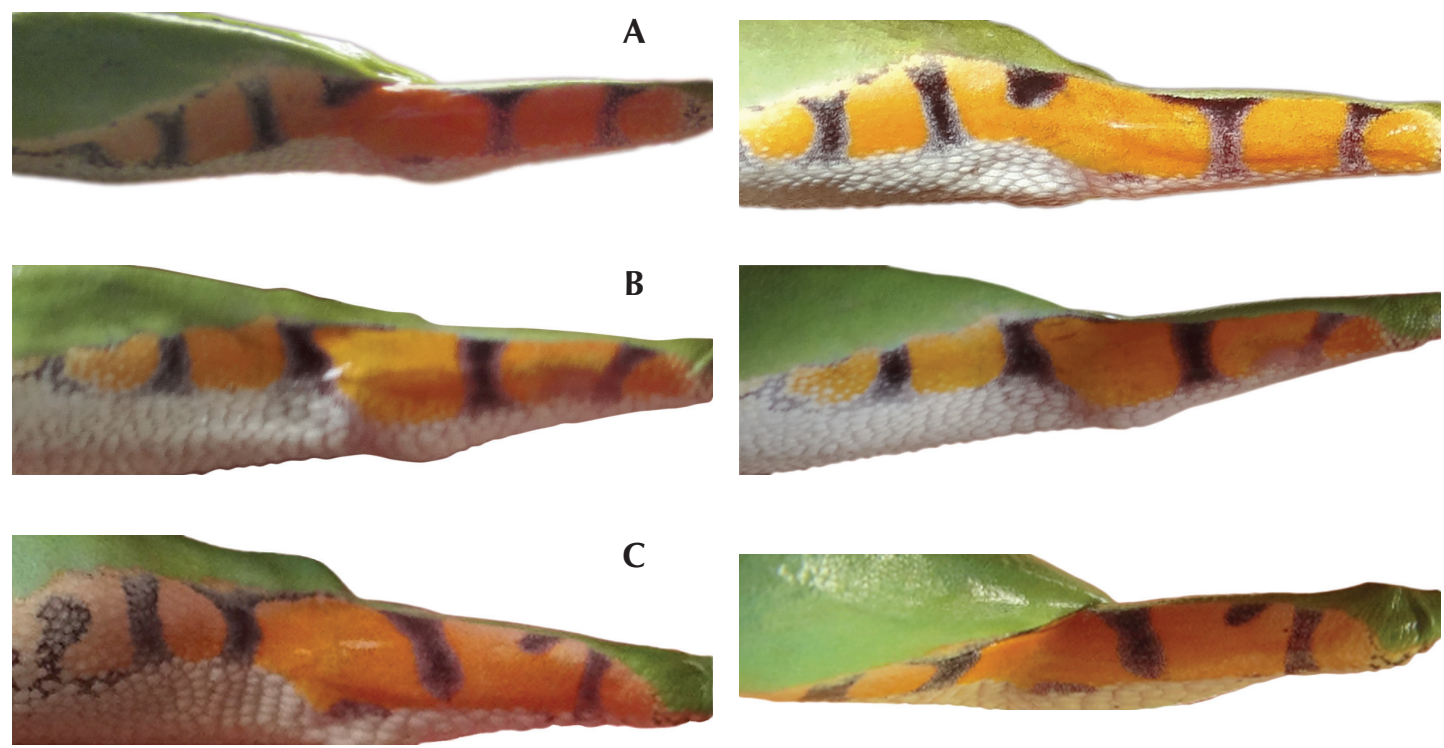

Figure 4. Results of three correspondence recaptures in the $\mathrm{I}^{3} \mathrm{~S}$ software. Images are presented as in Figure 3 . Images (A) and (B) matching the best, whereas image $(\mathbf{C})$ had a relatively low level of correspondence, probably due to the difference of angulation. 
The two photographic image-matching programs that we tested identified correct recaptures in the $70 \%$ range, but with a performance difference of $3.8 \%$. The $70 \%$ value is reasonably efficient and and about the same as those reported in other studies of the performance of computer-assisted photographic identification (e.g., Kenyon et al. 2009, Beirão et al. 2014). Although both programs only performed at the $70 \%$ level, the enhanced processing speed is beneficial. Thus, the use of PIM software seems to be a suitable alternative for many scientific purposes (e.g., avoidance of pseudo-replication).

The Wild.ID software is much more efficient than $\mathrm{I}^{3} \mathrm{~S}$ because it imports photographs so much more rapidly than does $I^{3} S(6946 \%$ slower than in Wild.ID), thereby decreasing the amount of time significantly to analyze the dataset. Several other studies also have commended the processing speed of Wild.ID relative to that of other software (Bendik et al. 2013, Halloran et al. 2015).

We conclude that both Wild.ID and $\mathrm{I}^{3} \mathrm{~S}$ are suitable to identify individual Pithecopus gonzagai by the inguinal color pattern of the thighs. The results reinforce the suitability of photographic identification methods for studies of phyllomedusid frogs (e.g., Oliveira et al. 2012, Oliveira 2017). However, it is worth noting that some photographic variables, such as photo angle and exposure, can adversely affect the accuracy of the software performance. We recommend standardizing the photography procedure to eliminate variants that will affect the performance of the software. Additionally, researchers should consider the sizes of their datasets. If the sample is large, then the speed of Wild.ID is advantageous, whereas $\mathrm{I}^{3} \mathrm{~S}$ is adequate for smaller samples.

\section{Acknowledgments}

We thank the Instituto Chico Mendes de Conservação da Biodiversidade for the collect permit (license $n^{\circ}$ 13587). FLA is also grateful to the class 2017.2 of the Comunicação Científica course of the Programa de Pós-Graduação em Ecologia e Conservação, Universidade Federal Rural do Semi-Árido (UFERSA) for their contributions to an early draft of this manuscript. This study was financed in part by the Coordenação de Aperfeiçoamento de Pessoal de Nível Superior (CAPES), Finance Code 001 (scholarship).

\section{References}

Andrade, F. S., I. A. Haga, J. S. Ferreira, S. M. ReccoPimentel, L. F. Toledo, and D. P. Bruschi. 2020. A new cryptic species of Pithecopus (Anura, Phyllomedusidae) in north-eastern Brazil. European Journal of Taxonomy 723: $108-134$.

Beirão, L., M. Cantor, L. Flach, and C. A. B. Galdino. 2014. Performance of computer assisted photographic matching of Guiana Dolphins (Sotalia guianensis). Aquatic Mammals 40: 313-316.

Bendik, N. F., T. A. Morrison, A. G. Gluesenkamp, M. S. Sanders, and L.J. O'Donnell. 2013. Computer-assisted photo identification outperforms visible implant elastomers in an endangered salamander, Eurycea tonkawae. PLOs ONE 8: e59424.

Bolger, D. T., T. A. Morrison, B. Vance, D. Lee, and H. Farid. 2012. A computer-assisted system for photographic mark-recapture analysis. Methods in Ecology and Evolution 3: 813-22.

Brasileiro, A. C., P. Cascon, D. C. Passos. 2021. How aggressive calls of a Neotropical treefrog vary among different levels of social tension? Ethology Ecology and Evolution 33: 1-8.

Brasileiro, A. C., F. Lima-Araujo, D. C. Passos, and P. Cascon. 2020. Are good fighters also good singers? The relationship between acoustic traits and fight success in the treefrog Pithecopus nordestinus (Phyllomedusidae). Acta Ethologica 23: 51-60.

Brown, L. J. 1997. An evaluation of some marking and trapping techniques currently used in the study of anuran population dynamics. Journal of Herpetology 31: 410 419.

Caci, G., A. B. Biscaccianti, L. Cistrone, L. Bosso, A. P. Garonna, and D. Russo. 2013. Spotting the right spot: computer-aided individual identification of the threatened Cerambycid beetle Rosalia alpina. Journal of Insect Conservation 17: 787-795. 
Caorsi, V. Z., R. R. Santos, and T. Grant. 2012. Clip or Snap? An evaluation of toe-clipping and photoidentification methods for identifying individual southern Red-Bellied Toads, Melanophryniscus cambaraensis. South American Journal of Herpetology 7: 79-84.

Caramaschi, U. 2006. Redefinição do grupo de Phyllomedusa hypochondrialis, com redescrição de $P$. megacephala (Miranda-Ribeiro, 1926), revalidação de $P$. azurea Cope, 1862 e descrição de uma nova espécie (Amphibia, Anura, Hylidae). Arquivos do Museu Nacional 64: 15979.

Carter, S. J. B., I. P. Bell, J. J. Miller, and P. P. Gash. 2014. Automated marine turtle photograph identification using artificial neural networks, with application to Green Turtles. Journal of Experimental Marine Biology and Ecology 452: 105-110.

Chim, C. K. and K. S. Tan. 2012. Recognition of individual knobby sea stars Protoreaster nodosus (L., 1758) using aboral surface characteristics. Journal of Experimental Marine Biology and Ecology 430-431: 48-55.

Clarke, R. D. 1972. The effect of toe clipping on survival in Fowler's Toad (Bufo woodhousei fowleri). Copeia 1972: $182-85$.

Correia, M., J. Palma, H. Koldewey, and J. P. Andrade. 2014. The use of a non-invasive tool for capturerecapture studies on a seahorse Hippocampus guttulatus population. Journal of Fish Biology 84: 872-884.

Dala-Corte, R. B., J. B. Moschetta, and F. G. Becker. 2016. Photo-identification as a technique for recognition of individual fish: a test with the freshwater Armored Catfish Rineloricaria aequalicuspis Reis and Cardoso, 2001 (Siluriformes: Loricariidae). Neotropical Ichthyology 14: e150074.

Del Lama, F., M. D. Rocha, M. A. Andrade, and L. B. Nascimento. 2011. The use of photography to identify individual tree frogs by their natural marks. South American Journal of Herpetology 6: 198-204.

Duellman, W. E., A. B. Marion, and B. Hedges. 2016. Phylogenetics, classification, and biogeography of the treefrogs (Amphibia: Anura: Arboranae). Zootaxa 4104: 1-109.

Frost, D. R. 2018. Amphibian Species of the World: an Online Reference. Version 6.0. Electronic Database accessible at https://amphibiansoftheworld.amnh.org/ index.php. American Museum of Natural History, New York, USA. Captured on 01 February 2020.

Funk, W. C., M. A. Donnelly, and K. R. Lips. 2005. Alternative views of amphibian toe-clipping. Nature 433: 193-193.
Gamble, L., S. Ravela, and K. McGarigal. 2008. Multi-scale features for identifying individuals in large biological databases: an application of pattern recognition technology to the Marbled Salamander Ambystoma opacum. Journal of Applied Ecology 45: 170-180.

Halloran, K. M., J. D. Murdoch, and M. S. Becker. 2015. Applying computer-aided photo-identification to messy datasets: a case study of Thornicroft's Giraffe (Giraffa camelopardalis thornicrofti). African Journal of Ecology 53: $147-155$.

Kenyon, N., A. D. Phillott, and R. A. Alford. 2009. Evaluation of the photographic identification method (PIM) as a tool to identify adult Litoria genimaculata (Anura: Hylidae). Herpetological Conservation and Biology 4: 403-410.

Kim, M. Y., A. Borzee, J. Y. Kim, and Y. Jang. 2017. Treefrog lateral line as a mean of individual identification through visual and software assisted methodologies. Journal of Ecology and Environment 41: 42.

Kniest, E., D. Burns, and P. Harrison. 2010. Fluke Matcher: a computer-aided matching system for Humpback Whale (Megaptera novaeangliae) flukes. Marine Mammal Science 26: 744-756.

Knox, C. D., A. Cree, and P. J. Seddon. 2013. Accurate identification of individual geckos (Naultinus gemmeus) through dorsal pattern differentiation. New Zealand Journal of Ecology 37: 60-66.

Langkilde, T. and R. Shine. 2006. How much stress do researchers inflict on their study animals? A case study using a scincid lizard, Eulamprus heatwolei. Journal of Experimental Biology 209: 1035-1043.

Long, Seh-ling and N. A. Azmi. 2017. Using photographic identification to monitor sea turtle populations at perhentian islands marine park in Malaysia. Herpetological Conservation and Biology 12: 350-66.

Markowitz, T. M., A. D. Harling, and B. Würsig. 2003. Digital photography improves efficiency of individual dolphin identification. Marine Mammal Science 19: 217-223.

Marshall, A. D. and S. J. Pierce. 2012. The use and abuse of photographic identification in sharks and rays. Journal of Fish Biology 80: 1361-1379.

May, R. M. 2004. Ecology: ethics and amphibians. Nature 431: 403.

Moro, M. F., M. B. Macedo, M. M. Moura-Fé, A. S. F. Castro, and R. C. Costa. 2015. Vegetação, unidades fitoecológicas e diversidade paisagística do estado do Ceará. Rodriguésia 66: 717-743. 
Oliveira, F. F., P. A. G. Nogueira, and P. C. Eterovick. 2012. Natural History of Phyllomedusa megacephala (Miranda-Ribeiro, 1926) (Anura: Hylidae) in Southeastern Brazil, with descriptions of its breeding biology and male territorial behaviour. Journal of Natural History 46: 117-29.

Oliveira, F. F. R. 2017. Mating behaviour, territoriality and natural history notes of Phyllomedusa ayeaye Lutz, 1966 (Hylidae: Phyllomedusinae) in south-eastern Brazil. Journal of Natural History 51: 11-12.

Tienhoven, A. M. V, J. E. Den Hartog, R. A. Reijns, and V. M. Peddemors. 2007. A computer-aided program for pattern-matching of natural marks on the spotted Raggedtooth Shark Carcharias taurus. Journal of Applied Ecology 44: 273-80.
Town, C., A. Marshall, and N. Sethasathien. 2013. Manta matcher: automated photographic identification of manta rays using keypoint features. Ecology and Evolution 3: 1902-14.

Vilaça, T. R. A., R. S. S. Silva, and M. Solé. 2011. Vocalization and territorial behaviour of Phyllomedusa nordestina Caramaschi, 2006 (Anura: Hylidae) from southern Bahia, Brazil. Journal of Natural History 45: 1823-1834.

Würsig, B. and M. Würsig. 1977. Photographic determination of group size, composition and stability of Coastal Porpoises (Tursiops truncatus). Science 198: 755-756.

Editor: J. P. Lawrence 